\title{
Analysis of Flood Disaster Mitigation Policy in Lamongan District
}

\author{
Achmad Aufa Anggarda ${ }^{1}$, , Hartuti Purnaweni' ${ }^{2}$, Sri Suwitri ${ }^{3}$, Teuku Afrizal ${ }^{4}$
}

1,2,3,4 Master of Public Administration, Faculty of Social and Political Sciences, Diponegoro University, Semarang, Indonesia

\section{ART I CLE IN F O}

Article history:

Received August 01, 2021

Revised August 03, 2021

Accepted October21, 2021

Available online November 25, 2021

Keywords:

Policy Analysis, Flood Disaster Mitigation, Policy Alternatives

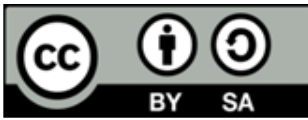

This is an open access article under the CC BY-SA license.

Copyright $@ 2021$ by Author. Published by Universitas Pendidikan Ganesha.

\begin{abstract}
A B S T RA C T
Flood is a frequent disaster in Indonesia, so it is an important public administration problem to overcome. This study aims to determine the flood disaster mitigation policy in Lamongan Regency. By knowing and analyzing this flood disaster mitigation policy, alternative policies are prepared that can be recommendations for the Lamongan Regency Government, especially the Regional Disaster Management Agency. Determination of policy alternatives uses 5 (five) stages in policy analysis according to Brigman \& Davis, namely formulating problems in policy, determining goals and objectives, determining policy parameters, seeking policy alternatives, and deciding alternative options. The purpose of this study is to formulate and determine the best policy alternatives to overcome problems in the implementation of flood disaster mitigation in the Lamongan Regency. The research method is carried out by analyzing data through supporting documents, journals, books, and other references. The study results indicate that current policy problems have not led to flood disaster mitigation, but rather 'wait' until the flood disaster occurs, then the Government and BPBD Lamongan Regency only act by assisting flood victims. The proposed alternative policy is the prevention, handling, and recovery of flood disaster mitigation in the Lamongan Regency area with community participation.
\end{abstract}

\section{INTRODUCTION}

Indonesia is a country that has a high level of vulnerability to natural disasters such as volcanic eruptions, earthquakes, tsunamis, floods, and landslides (Gan et al., 2021; Nasution et al., 2020). At least during 2020, there were 1,080 flood disasters out of 2,952 disasters that occurred in Indonesia. The causes of flooding in Indonesia generally occur due to logging without reforestation, dumping garbage in rivers, and building houses on riverbanks (Irawan et al., 2021; Merten et al., 2021). These factors result in a decrease in the function of the watershed (DAS) and can cause severe flooding that occurs. Increased rainfall intensity can encourage flooding. The increase in rainfall is influenced by the factor of increasing global temperature which has an impact on the acceleration of the hydrological cycle. Flooding is defined as the flow of water on the ground surface which is relatively high and cannot be accommodated by drainage channels or rivers, so that it exceeds the river body and causes inundation or flow in amounts that exceed normal and results in losses for humans (Buchori et al., 2021; Nasri et al., 2020; Wardhono, 2012). Natural disasters often occur in unexpected ways and beyond human estimates so that emergency disaster response activities or actions are needed (Arviansyah et al., 2021; Muir et al., 2020; Yulianto et al., 2021). In Government Regulation number 21 of 2008 concerning the Implementation of Disaster Management, it is stated that disaster emergency response is a series of activities carried out immediately at the time of a disaster to deal with the adverse effects caused, which include rescue and evacuation of victims, property, fulfillment basic needs, protection of refugee management, rescue, and restoration of infrastructure and facilities.

Flooding is influenced by three factors, namely meteorology, watershed characteristics, and human behavior (Afriyanie et al., 2010; Ghozali et al., 2016). Flooding can be influenced by the characteristics of the watershed (DAS) in the form of landform, elevation, soil type, and the slope of land. In order to prevent or minimize the adverse effects of flood disasters, efforts can be made, namely mitigation (Karunarathne, 2021; Rana et al., 2021). Disaster mitigation is one of the most important steps taken as a benchmark in disaster control (Kumar et al., 2021; Maizar et al., 2021). There are four important things in disaster mitigation in general, namely: the existence of information and maps of the area of each 
type of disaster, the socialization of increasing public understanding and awareness in disaster management, especially those who live in disaster-prone areas, knowledge of the actions that need to be taken and avoided in disasters that occur, and the existence of regulation and arrangement of disasterprone areas to reduce the threat of disasters (Sattar et al., 2020; Syamsidik et al., 2021). One of the areas in East Java that is prone to and frequent floods is Lamongan Regency. Almost every year when the rainy season arrives, thousands of houses and dozens of villages are inundated by overflowing floods from the longest river in Java, the Bengawan Solo River.

Based on sources from BPBD Lamongan 2016 - 2020, Lamongan Regency experiences the floods disaster every year. From 2016 to 2020, on average, more than six sub-districts were flooded in Lamongan Regency. The flood disaster will have a large impact on losses because many ponds and rice fields have failed to harvest and farmers have suffered losses. Lamongan Regency has an area of approximately $1,812.8 \mathrm{~km}^{2}$ or $\pm 3.78 \%$ of the total area of East Java Province. With a coastline of $47 \mathrm{~km}$ and the sea area of Lamongan Regency is $902.4 \mathrm{~km}^{2}$ and 12 miles from sea level. The mainland of Lamongan Regency is geographically divided by the Bengawan Solo River which does have a wide and large watershed. Disaster mitigation is a mandate from the 1945 Constitution which is then explained in general terms by Permendagri No. 33 of 2006, and also included in Law no. 24 of 2007 concerning Disaster Management which is then explained about its implementation in Government Regulation no. 21 of 2008. With this legal force, disaster mitigation activities are official and legal to be carried out throughout the territory of the Republic of Indonesia. One of them is in Bedono Village, Sayung Subdistrict, Demak Regency, Central Java. In this village, every year it is definitely affected by tidal floods from the north sea of Java, so the people of this area make adaptation policies and programs, namely physical adaptation, economic adaptation, and social adaptation (Haloho \& Purnaweni, 2020).

According to the author's examination, almost all regions already have and implement disaster mitigation including flood disasters. In particular, areas or cities that are regularly affected by floods every year, such as Jakarta, Semarang, and Surabaya, including Lamongan Regency, but in practice not everything can run according to the concepts and programs that have been proclaimed. Based on the problems described, the authors are interested in researching flood disaster mitigation policies in Lamongan Regency. The purpose of this research is to formulate and determine the best alternative policy as an effort to deal with problems in the implementation of flood disaster mitigation in Lamongan Regency.

\section{METHODS}

This research is a literature review study related to flood disaster mitigation in Lamongan Regency. We conducted this literature review between April and May 2021 by surveying literature from Google Scholar and Research Gate, both Indonesian-language literature and English-language literature. Researchers chose Google Scholar and Research Gate because they are sites that provide article and journal services that are easily accessible and quite complete in their presentation, especially for domestic research that is included in the criteria in this study. From the initial search results of researchers at Google Scholar and Research Gate, there are around 2660 literatures in English and Indonesian related to flood mitigation policies. From 2660 literatures, then carefully selected which ones are really relevant to the purpose of this research and in accordance with the 5 stages of policy analysis from Brigman \& Davis (Badjuri \& Abdulkahar, 2003).

This study aims to analyze the flood disaster mitigation policy in Lamongan Regency, then provide policy alternatives as recommendations to the Lamongan Regency Government, especially the Lamongan Regency Regional Disaster Management Agency (BPBD) in its steps to overcome floods that always occur in Lamongan Regency. In this study, policy alternatives were compiled as a result of 5 (five) stages of policy analysis namely: formulating problems in policies, determining goals and objectives, identifying policy parameters, seeking policy alternatives, and deciding alternative options. In the implementation of these 5 (five) stages, data analysis is carried out carefully on the data that has been obtained through official documents and literature reviews from the Google Scholar and Research Gate sites (Badjuri \& Abdulkahar, 2003).

\section{RESULTS AND DISCUSSIONS}

\section{Results}

Every year, Lamongan Regency will experience floods. This is due to its position which passed by large rivers (Bengawan Solo and Bengawan Jero) which always overflow when the rainy season arrives. The problem is that the overflow can last up to two months longer, thus hampering the daily activities of residents. The results of research show that moderate to high levels of floods are located in 10 sub-districts 
of Lamongan Regency (Wahid, 2015). The area that has a high level of flood risk is 15,101.80 ha (8.64\%), while the area that has a moderate and low level of flood risk is $122,465.35$ ha $(7.13 \%)$ and $147,237.34$ ha (84.23\%). Flood risk management in Lamongan Regency has actually been going well. This can be seen from the reduced impact caused by the flood disaster, although there are still some shortcomings in terms of institutions, policies, handling mechanisms, and community participation. The current flood disaster management and mitigation policies have not been able to overcome this annual flood problem, where according to sources from various national media, the problem of flooding in 2021 in Lamongan Regency, it has been going on for almost 3 months from the end of December 2020 to March 2021. The Lamongan Regency government has actually tried to overcome this flood problem, starting with repairing and building infrastructure along the Bengawan Jero watershed, procuring flood pumps, and even using amphibious backhoes to clean water hyacinth plants that block river water flow. However, until now, there is no policy that does lead to flood disaster mitigation. So the current policies tend or seem to only 'wait' until a flood occurs, then the Government and the Lamongan Regency BPBD have just acted to overcome it by simply providing assistance to flood victims. The policies made by the Lamongan Regency government related to disaster mitigation, especially flood disasters, should be formulated, programmed, socialized, and realized as soon as possible when the rainy season ends, considering that this flood disaster occurs regularly and has not been completely resolved until now.

Referring to the vision and mission of the Lamongan Regency BPBD, the general BPBD coordination functions include; Regulation, institutional, planning, implementation and funding. BPBD has the authority to share the roles of each SKPD in disaster management. It is hoped that every SKPD involved in disaster management can work optimally in order to reduce the risk of a disaster. In the process of disaster management, especially flood disaster management, the Lamongan Regency BPBD collaborates with several agencies including PMI, Public Works Agency, Irrigation Service, Agriculture Service, Social Service, Health Service and Education Office. BNPB Lamongan Regency as a disaster management agency, has a vision of resilience in dealing with disasters. To support the vision of BNPB, 5 (five) missions must be carried out as the direction and limits of the process of achieving these goals: (1) Protect the nation from the threat of disaster with build a culture of disaster risk reduction and disaster preparedness to become an integrated part of national development; (2) Build a disaster emergency management system quickly, effectively and efficiently; (3) Organizing post-disaster area and community recovery through better coordinated rehabilitation and reconstruction and with the dimension of disaster risk reduction; (4) Organizing support and management of logistics and disaster management equipment; and (5) Organizing disaster management in a transparent manner with the principles of good governance (Rustinsyah et al., 2021). So, the main goals and objectives of the flood disaster mitigation policy are to reduce and minimize the risk of disasters widely by working between all related parties for the common benefit.

Parameter is the size of the entire population in the study that must be estimated from that contained in the sample. This means that if we interpret the policy parameters, namely the size or benchmark used for policies to be taken or implemented by certain regions, in this case a special policy for the Lamongan Regency area with/according to the current conditions and situations. The policy issued is an effort to overcome and to prevent problems that will arise in the future. Therefore, it is very necessary to have a unified measure in formulating an appropriate policy. Consideration must be made of various factors that influence and are influenced in making the policy. The main policy parameters in the recommendation of alternative flood mitigation policies in Lamongan Regency are based on Permendagri No. 33 of 2006 concerning General Guidelines for Disaster Mitigation, Law no. 24 of 2007 concerning Disaster Management, PP No. 21 of 2008 concerning the Implementation of Disaster Management, and the BNPB Strategic Plan for 2015-2019. With this legal basis, the policy in question is expected to be able to synergize with the central government, including the Central BNPB. One of the other policy parameters in terms of flooding in Lamongan district is that regular flooding causes delays in the economic pace of Lamongan residents where roads, markets and rice fields are flooded for quite a long time, it could be a week or even months.

\section{Discussion}

We have made the following alternative policies for the Lamongan Regency government (BPBD Lamongan Regency). This policy alternative is specifically made for flood disaster mitigation, which consists of: first, policy formulation. All relevant parties met and agreed that this flood is a common problem and must be resolved together with the support and involvement of all parties. Second, arrangement. The local government by involving the BPBD and all related parties (society) makes arrangements related to the formulation and enforcement of policies and the regulations contained therein. Third, representative. Representatives from local governments bring the results of the policy 
formulation and consult with the central government. This function is important in determining the weight and influence of regional and central governments, including their funding. Fourth, Planning and coordination in itself is not a highly financed function, but this role may require major responsibility for implementing major development programs that are financed either by local government or by the central government. This includes socialization to residents who are usually affected by this flood disaster (Pahleviannur, 2019; Sari et al., 2020; Winoto, 2020).

Fifth, facility repair and construction. Repairs and construction of facilities are carried out after the alternative policies are approved and ratified. Repair and construction of facilities must be oriented towards the environment and society, so if possible, it is not only flood disaster management (Kim et al., 2021; Rana et al., 2021; Rustinsyah et al., 2021). This repair can be in the form of repairing regional/village roads, repairing waterways, and repairing equipment commonly used during flood conditions (Ma et al., 2021; Rustinsyah et al., 2021; Stoklosa et al., 2021). For the construction of facilities such as the construction of integrated waste disposal and processing facilities, the construction of waste water channels in accordance with environmental hygiene standards, and the construction of stone walls/embankments along the Bengawan Solo and Bengawan Jero watershed. Sixth, prevention, treatment and recovery. In general, there are three parts to disaster management, namely prevention, handling, and recovery. Here the role of the community as affected parties and those who want this flood problem to be resolved immediately, play a major role in the implementation of this alternative policy. With the support of all levels of society, alternative policies with community participation will greatly help many parties, including the government and the community itself.

Activities in the Flood Mitigation Cycle (management) that can be used in solving flood problems in Lamongan Regency are as follows: first, prevention. Structural Efforts (Efforts within the river body (InStream) and efforts outside the river body (Off-Stream)). Non-Structural Measures (Long-term flood prevention efforts and short-term flood emergency management efforts). Second, handling (Intervention/Response). Notification and dissemination of flood forecast information; Quick response and assistance in handling flood emergencies; and Resistance to flooding. Third, recovery. Immediate assistance for daily living needs and repair of facilities and infrastructure; Post flood cleaning and reconstruction; Rehabilitation and restoration of physical condition and non-physical; Damage/loss assessment and flood insurance; and Study of causes of flood disaster. All of the above activities are mitigation alternatives chosen from the policy alternatives carried out in the previous stage (Caldas et al., 2020; Maizar et al., 2021; Stasiewicz \& Paveglio, 2021). It should be remembered that all of the above flood mitigation cycle activities cannot be successful in their implementation if they are only carried out with the role of the government (both regional and central), without community participation (Alabbad et al., 2022; Kourtis et al., 2021). So, the participation of the community (especially related parties) with the government makes this alternative the best alternative to deal with floods that routinely occur.

The recommendation that the researcher gave on the results of the analysis of flood mitigation policies in Lamongan Regency refers to community participation, especially the people of Lamongan Regency itself. With the principle of mutual cooperation and mutual assistance, it will make a strategy for community participation to quickly and precisely overcome flood disasters that regularly occur (Jiang \& Faure, 2020; Moura et al., 2020). In every process, starting from prevention, handling, and restoration of areas or communities affected by floods, the government as a policy maker should issue regulations that allow and guarantee public participation in making the area or environment ready to face the flood disaster that occurs. The government and all community leaders are expected to be able to socialize and also become role models in the implementation and development of this community participation strategy, so that all levels can be represented and resolved problems related to this flood. It is hoped that in the flood mitigation policy, which will have community participation, there will be no more rules that make it difficult and limit the community in the process of preventing, handling, and recovering flood disasters in Lamongan Regency.

\section{CONCLUSION}

The study of documents, journals, books and other references in analyzing flood disaster mitigation policies in Lamongan Regency is carried out in 5 (five) stages. After going through each of these stages, finally an alternative policy that is considered the most suitable for mitigating the annual flood disaster that regularly occurs in Lamongan Regency is found. The results of the study indicate that there are currently no policy problems that lead to flood disaster mitigation. The current policy is only to 'wait' until the flood disaster occurs, then the Government and the Lamongan Regency BPBD have just acted to overcome it by simply providing assistance to flood victims. The proposed alternative policy is the prevention, handling, and recovery of flood disaster mitigation in the Lamongan Regency area with community participation. 


\section{REFERENCES}

Afriyanie, D., Julian, M. M., Riqqi, A., Akbar, R., Suroso, D. S. A., \& Kustiwan, I. (2010). Re-framing urban green spaces planning for flood protection through socio-ecological resilience in Bandung City, Indonesia. Cities, 101. https://doi.org/10.1016/j.cities.2020.102710.

Alabbad, Y., Yildirim, E., \& Demir, I. (2022). Flood mitigation data analytics and decision support framework: Iowa Middle Cedar Watershed case study. Science of The Total Environment, 814. https://doi.org/10.1016/j.scitotenv.2021.152768.

Arviansyah, A., Kusumastuti, R. D., Nurmala, N., \& Wibowo, S. S. (2021). Data on knowledge management and natural disaster preparedness: A field survey in East Lombok, Indonesia. Data in Brief, 36. https://doi.org/10.1016/j.dib.2021.107156.

Badjuri, \& Abdulkahar. (2003). Kebijakan Publik: Konsep dan strategi. Universitas Diponegoro.

Buchori, I., Pramitasari, A., Pangi, P., Sugiri, A., Maryono, M., Basuki, Y., \& Sejati, A. W. (2021). Factors distinguishing the decision to migrate from the flooded and inundated community of Sayung, Demak: A suburban area of Semarang City, Indonesia. International Journal of Disaster Risk Reduction, 52. https://doi.org/10.1016/j.ijdrr.2020.101946.

Caldas, L. R., Saraiva, A. B., Andreola, V. M., \& Filho, R. D. T. (2020). Bamboo bio-concrete as an alternative for buildings' climate change mitigation and adaptation. Construction and Building Materials, 263. https://doi.org/10.1016/j.conbuildmat.2020.120652.

Gan, C. C. R., Oktari, R. S., Nguyen, H. X., Yuan, L., Yu, X., Alisha, Hanh, T. T. T., Phung, D. T., \& Dwirahmadi, F. (2021). A scoping review of climate-related disasters in China, Indonesia and Vietnam: Disasters, health impacts, vulnerable populations and adaptation measures. International Journal of Disaster Risk Reduction, 66. https://doi.org/10.1016/j.ijdrr.2021.102608.

Ghozali, A., Ariyaningsih, Sukmara, R. B., \& Aulia, B. U. (2016). A Comparative Study of Climate Change Mitigation and Adaptation on Flood Management between Ayutthaya City (Thailand) and Samarinda City (Indonesia). Procedia - Social and Behavioral Sciences, 227. https://doi.org/10.1016/j.sbspro.2016.06.096.

Haloho, E. H., \& Purnaweni, H. (2020). Adaptasi Masyarakat Desa Bedono Terhadap Banjir Rob di Kecamatan Sayung, Kabupaten Demak, Jawa Tengah. Journal of Public Policy and Management Review, 9(4). https://doi.org/10.14710/jppmr.v9i4.28997.

Irawan, A. M., Marfai, M. A., Munawar, Nugraheni, I. R., Gustono, S. T., Rejeki, H. A., \& Widodo, A. (2021). Comparison between averaged and localised subsidence measurements for coastal floods projection in 2050 Semarang, Indonesia. Urban Climate, 35. https://doi.org/10.1016/j.uclim.2020.100760.

Jiang, M., \& Faure, M. (2020). Risk-sharing in the context of fishery mutual insurance: Learning from China. Marine Policy, 121. https://doi.org/10.1016/j.marpol.2020.104191.

Karunarathne, A. Y. (2021). Geographies of the evolution of social capital legacies in response to flood disasters in rural and urban areas in Sri Lanka. International Journal of Disaster Risk Reduction, 62. https://doi.org/10.1016/j.ijdrr.2021.102359.

Kim, J.-M., Yum, S.-G., Park, H., \& Bae, J. (2021). A deep learning algorithm-driven approach to predicting repair costs associated with natural disaster indicators: The case of accommodation facilities. Journal of Building Engineering, 42. https://doi.org/10.1016/j.jobe.2021.103098.

Kourtis, I. M., Bellos, V., Kopsiaftis, G., Psiloglou, B., \& Tsihrintzis, V. A. (2021). Methodology for holistic assessment of grey-green flood mitigation measures for climate change adaptation in urban basins. Journal of Hydrology, 603. https://doi.org/10.1016/j.jhydrol.2021.126885.

Kumar, P. G., Tejaswini, V., Rao, P. K., \& Shankar, G. J. (2021). Disaster mitigation and its strategies in a global context - a state of the art. Materials Today: Proceedings, 45(7). https://doi.org/10.1016/j.matpr.2020.11.369.

Ma, L., Yang, L., Jiang, X., \& Huang, D. (2021). Analysis of business interruption risk factors of Chinese enterprises during flood disasters based on social network analysis. Climate Risk Management, 33. https://doi.org/10.1016/j.crm.2021.100353.

Maizar, E., Gayatri, D., \& Nuraini, T. (2021). Knowledge of mitigation and attitude of preparedness of vocational health programs students in Jakarta in facing earthquake disasters. Enfermería Clínica, 31(2). https://doi.org/10.1016/j.enfcli.2020.09.037.

Merten, J., Nielsen, J. Ø., Rosyani, Soetarto, E., \& Faust, H. (2021). From rising water to floods: Disentangling the production of flooding as a hazard in Sumatra, Indonesia. Geoforum, 118. https://doi.org/10.1016/j.geoforum.2020.11.005. 
Moura, E. H. de, Cruz, T. B. R. e, \& Chiroli, D. M. D. G. (2020). A framework proposal to integrate humanitarian logistics practices, disaster management and disaster mutual assistance: A Brazilian case. Safety Science, 132. https://doi.org/10.1016/j.ssci.2020.104965.

Muir, J. A., Cope, M. R., Angeningsih, L. R., \& Brown, R. B. (2020). Community recovery after a natural disaster: Core data from a survey of communities affected by the $2010 \mathrm{Mt}$. Merapi eruptions in Central Java, Indonesia. Data in Brief, 32. https://doi.org/10.1016/j.dib.2020.106040.

Nasri, R. I., Seniwati, T., Ilkafah, \& Erfina, E. (2020). Screening of post-traumatic stress disorder (PTSD) among flood victims in Indonesia. Enfermería Clínica, 30(2). https://doi.org/10.1016/j.enfcli.2019.07.115.

Nasution, B. I., Kurniawan, R., Siagian, T. H., \& Fudholi, A. (2020). Revisiting social vulnerability analysis in Indonesia: An optimized spatial fuzzy clustering approach. International Journal of Disaster Risk Reduction, 51. https://doi.org/10.1016/j.ijdrr.2020.101801.

Pahleviannur, M. R. (2019). Edukasi Sadar Bencana Melalui Sosialisasi Kebencanaan Sebagai Upaya Peningkatan Pengetahuan Siswa Terhadap Mitigasi Bencana. Jurnal Pendidikan Ilmu Sosial, 29(1). https://doi.org/10.23917/jpis.v29i1.8203.

Rana, I. A., Asim, M., Aslam, A. B., \& Jamshed, A. (2021). Disaster management cycle and its application for flood risk reduction in urban areas of Pakistan. Urban Climate, 38. https://doi.org/10.1016/j.uclim.2021.100893.

Rustinsyah, R., Prasetyo, R. A., \& Adib, M. (2021). Social capital for flood disaster management: Case study of flooding in a village of Bengawan Solo Riverbank, Tuban, East Java Province. International Journal of Disaster Risk Reduction, 52. https://doi.org/10.1016/j.ijdrr.2020.101963.

Sari, U. A., Yasri, H. L., \& Arumawan, M. M. (2020). Sosialisasi Mitigasi Bencana Banjir Melalui Pendidikan Kebencanaan Berbasis Kearifan Lokal. Jurnal Masyarakat Mandiri, 4(4). https://doi.org/10.31764/jmm.v4i4.2087.

Sattar, M. A., Biswas, A. A. A., Islam, M. T., Hossain, M. A., Siddeqa, M., \& Rahim, M. A. (2020). Disaster vulnerability and mitigation of humanitarian issues in coastal Bangladesh: Local evidence and knowledge gaps. Progress in Disaster Science, 8. https: //doi.org/10.1016/j.pdisas.2020.100138.

Stasiewicz, A. M., \& Paveglio, T. B. (2021). Preparing for wildfire evacuation and alternatives: Exploring influences on residents' intended evacuation behaviors and mitigations. International Journal of Disaster Risk Reduction, 58. https://doi.org/10.1016/j.ijdrr.2021.102177.

Stoklosa, H., Burns, C. J., Karan, A., Lyman, M., Lyman, M., Morley, N., \& Tadee, R. (2021). Mitigating trafficking of migrants and children through disaster risk reduction: Insights from the Thailand flood. International Journal of Disaster Risk Reduction, 60. https://doi.org/10.1016/j.ijdrr.2021.102268.

Syamsidik, Oktari, R. S., Nugroho, A., Fahmi, M., Suppasri, A., \& Munadi, K. (2021). Fifteen years of the 2004 Indian Ocean Tsunami in Aceh-Indonesia: Mitigation, preparedness and challenges for a long-term disaster recovery process. International Journal of Disaster Risk Reduction, 54. https://doi.org/10.1016/j.ijdrr.2021.102052.

Wahid, A. A. (2015). Manajemen Risiko Banjir di Kabupaten Lamongan. Universitas Gadjah Mada.

Wardhono, A. (2012). Countermeasures Flood Disaster Sampean River Policy in Situbondo District. Journal of Law and Social Sciences (JLSS), 2(1). https: //doi.org/10.5176/2251-2853_2.1.65.

Winoto, P. M. P. (2020). Pengaruh Sosialisasi Kesiapsiagaan Bencana Melalui Metode Simulasi Terhadap Peningkatan Ketrampilan Dalam Mengahadapi Bencana Pada Mahasiswa Siaga Bencana (Magana) Universitas Nahdlatul Ulama Surabaya. Jurnal Ilmiah Kesehatan, 13(2). https://doi.org/10.33086/jhs.v13i2.1474.

Yulianto, E., Yusanta, D. A., Utari, P., \& Satyawan, I. A. (2021). Community adaptation and action during the emergency response phase: Case study of natural disasters in Palu, Indonesia. International Journal of Disaster Risk Reduction, 65. https://doi.org/10.1016/j.ijdrr.2021.102557. 